\title{
PRAKTIK MONOPOLI YANG DILAKUKAN OLEH BUMN DITINJAU DARI HUKUM PERSAINGAN USAHA (STUDI KASUS PUTUSAN KPPU NOMOR 15/KPPU-L/2018)
}

\author{
Oleh: \\ Arda Alvin Pandu Ekaputra', Bonita $^{2}$, Rani Apriani ${ }^{3}$ \\ ${ }^{1}$ Universitas Singaperbangsa Karawang; ardaalvinpandu@gmail.com \\ ${ }^{2}$ Universitas Singaperbangsa Karawang; bonitatha@gmail.com \\ ${ }^{3}$ Universitas Singaperbangsa Karawang; rani.apriani180488@gmail.com
}

\begin{abstract}
ABSTRAK: Penelitian ini bertujuan untuk mengetahui dan memahami makna dari pengecualian terhadap Badan Usaha Milik Negata (BUMN) yang terdapat dalam UU No. 5/1999 terhadap implementasinya pada kasus PT Pelabuhan Indonesia III. Metode penelitian yang digunakan ialah metode yuridis normatif. Hasil penelitian menujukkan bahwa PT Pelabuhan Indonesia III melakukan praktik monopoli sesuai dengan unsurunsur yang terkait. Memerlukan pengawasan yang ekstra terhadap perusahaan BUMN serta terdapat nilai ketidakadilan yang dirasa dalam aturan tersebut dan perlunya kajian lebih komprehensif perlunya revisi terkait UU No. 5/1999 tersebut.
\end{abstract}

\section{KATA KUNCI: Praktik Monopoli, BUMN, Pengecualian}

ABSTRACT: This research aims to know and understand the meaning of the exception to State-Owned Enterprises (SOEs) contained in Law No. 5/1999 on its implementation in the case of PT Pelabuhan Indonesia III. The research method used is normative juridical method. The results showed that PT Pelabuhan Indonesia III conducted monopoly practices in accordance with the relevant elements. It requires extra supervision of stateowned companies and there is a value of injustice felt in the rule and the need for a more comprehensive review of the need for revisions related to Law No. 5/1999.

KEYWORDS: Monopoly Practices, State-Owned Enterprises (SOEs), Exceptions

\section{PENDAHULUAN}

Indonesia pada dasarnya merupakan negara hukum yang harus tunduk pada konstitusi yang berlaku. ${ }^{1}$ Sebagai negara hukum, Indonesia mempunyai konstitusi yang berguna dalam memberikan suatu kepastian hukum terhadap masyarakatnya. ${ }^{2}$ Segala ketentuan dan aturan yang terdapat dalam UUD Tahun 1945 itulah juga mesti disusun dengan baik agar terwujudnya

${ }^{1}$ Lihat Pasal 1 Ayat (3) UUD NRI Tahun 1945 ${ }^{2}$ Muhammad Erwin, Pendidikan Kewarganegaraan Republik Indonesia, Bandung: PT Refika Aditama, 2017, hlm. 152 kepastian yang menjadi tujuan hukum itu sendiri sesuai dengan harapan masyarakatnya. Hal ini selaras terhadap pendapat Gustav Radbruch ${ }^{3}$, dimana suatu konstitusi yang baik, maka harus memenuhi tiga kriteria, diantaranya kriteria secara filosofis, sosiologis, dan yuridis. Secara yuridis inilah menjadi tonggak bahwa konstitusi harus menciptakan kepastian bagi masyarakat.

Salah satu aturannya mengatur tentang bagaimana filosofi negara dalam

${ }^{3}$ Gustav Radbruch, Einfuhrung in die Rechtswissenchaft, Stugart: K.F.Koechler, 1961, hlm. 36 
mewujudkan kesejahteraan masyarakatnya yang tercantum dalam Pasal 33 UUD Tahun 1945 yang sesuai dengan tujuan negara yang terdapat pada alinea keempat pembukaan UUD Tahun 1945, ialah memajukan kesejahteraan umum. Pasal 33 UUD Tahun 1945 ini mengatur persoalan falsafalah tentang demokrasi ekonomi. Peraturan tersebut mencantumkan dan berisikan semua hal yang berkaitan dengan ekonomi. Saat memahami Pasal 33 tersebut dikatakan bahwa dasar demokrasi ekonomi ialah produksi yang dilaksanakan oleh setiap orang di bawah pimpinan atau pengawasan masyarakat. Prioritasnya ialah kesejahteraan masyarakat, kesejahteraan yang tidak dapat diganggu gugat oleh kepentingan apa pun. Kesejahteraan untuk rakyat, bukan untuk kesejahteraan individu. Oleh karena itu, perekonomian yang dimaksud berdasarkan asas kekeluargaan dan aturan tersebut berorientasi pada ekonomi kerakyatan. ${ }^{4}$ Pasal 33 inilah juga menjadi dasar bahwa terdapat banyak cara untuk mewujudkan kesejahteraan itu, salah satunya dengan membentuk hukum persaingan usaha melalui UU No. 5 Tahun 1999 tentang Larangan Praktek Monopoli dan Persaingan Usaha Tidak Sehat. Undang-undang ini bertujuan untuk mewujudkan demokrasi ekonomi sebagai tumpuan perekonomian dan politik negara. Demokrasi ekonomi tersebut mempunyai tujuan yang ditentukan dalam Pasal 3 UU No. 5 Tahun 1999 dan dapat memiliki beberapa tujuan umum, seperti mencegah perilaku monopoli dan atau persaingan bisnis yang tidak sehat. Disebabkan oleh pelaku usaha. ${ }^{5}$

Dengan adanya tujuan tersebut, selain untuk mencegah perilaku monopoli bisa dilakukan oleh pelaku bisnis harus

${ }^{4}$ Nadir, Membidik Persaingan Tidak Sehat Dengan Hukum Anti Monopoli dan Persaingan Tidak Sehat, Malang: UB Press, 2015, hlm. 127 dapat menjaga kepentingan bersama tanpa adanya unsur dari luar yang menganggu dan meningkatkan efisiensi ekonomi nasional untuk meningkatkan kesejahteraan masyarakat. Kesejahteraan masyarakat dapat bertolak belakang dengan adanya kepentingan yang melakukan kegiatan yang bertujuan untuk diri sendiri. Hal itu bertentangan dengan adanya kepentingan umum yang harus di pegang dengan teguh sesuai dengan aturan yang terdapat dalam hukum persaingan usaha.

Hukum persaingan usaha juga harus ditegakkan dan dijalankan oleh semua pelaku usaha yang bergerak di dalam bidang ekonomi untuk menunjang adanya pembangunan ekonomi yang secara jelas dapat memberikan kesejahteraan bagi negara maupun masyarakatnya. Aturan tersebut juga mesti ditegakkan dengan seadil-adilnya tanpa membedakan status yang dimiliki oleh pelaku usaha, baik itu lembaga maupun perorangan. Lembaga atau perorangan yang terikat dalam hukum persaingan usaha semestinya menjalankan kegiatan usahanya dengan prinsip persaingan secara sehat dengan mengindahkan segala peraturan yang tercantum untuk menghindar adanya kesenjangan atau menimbulkan kerugian akibat suatu hal yang tidak inginkan.

Sementara adanya UU No. 5 Tahun 1999 tentang Larangan Praktek Monopoli dan Persaingan Usaha Tidak Sehat ini bukanlah solusi yang relevan dengan era saat ini. Persaingan usaha yang terjadi menimbulkan masalah yang terjadi hingga saat ini, sehingga persaingan usaha ialah titik sentral kegiatan usaha yang akan meningkatkan pembangunan ekonomi negara untuk lebih maju dengan menciptakan pelaku usaha yang hebat, sehingga membawa

${ }^{5}$ Lihat Pasal 3 UU No. 5 Tahun 1999 
negara ini menjadi berkehidupan yang lebih baik dalam sektor perekonomian. Oleh karena itu, sektor perekonomian tersebut membutuhkan regulasi dan kelembagaan yang memadai untuk mengelola dan merespon terhadap masalah atau isi terhadap persaingan usaha ini. ${ }^{6}$ Lembaga tersebut sudah ada di Indonesia yang bernama Komisi Pengawas Persaingan Usaha (KPPU).

Namun, khususnya dalam UU No. 5 Tahun 1999 pembahasan tentang keadilan secara substansial telah merugikan pelaku usaha tertentu, karena UU No. 5 Tahun 1999 ini mengecualikan lembaga yang termasuk Badan Usaha Milik Negara (BUMN). Padahal, karena BUMN melakukan monopoli alamiah hal ini wajar secara teknis, sehingga pengecualian semacam ini juga bisa dipahami dan dibuktikan secara normatif. Namun yang menjadi persoalan, lembaga BUMN cenderung menyalahgunakan kekuasaan monopoli yang berdampak merugikan bagi konsumen, dan dapat melanggar salah satu cita-cita hukum berdasarkan UUD Tahun $1945 .^{7}$ Secara jelasnya hal tersebut diatur dalam Pasal 51 UU No. 5 Tahun 1999 yang menyebutkan bahwa BUMN atau lembaga yang ditunjuk oleh pemerintah memiliki kewenangan untuk melaksanakan monopoli.

Pada dasarnya monopoli itu tidak dilarang berdasarkan ketentuan UU No. 5 Tahun 1999, tetapi praktik monopoli yang termasuk dalam kegiatan yang dilarang. Monopoli dalam hal tersebut bukan sebagai kegiatan yang dilarang harus dalam ketentuan syarat yang mengedepankan prinsip-prinsip persaingan usaha secara sehat. ${ }^{8}$ Prinsip

\footnotetext{
${ }^{6}$ Nadir, Op.Cit, hlm. 141

${ }^{7}$ Ibid.

${ }^{8}$ Abdul Rahman, Hukum Persaingan Usaha, Sleman: Deepublish, 2018, hlm. 292

9 C.S.T Kansil, Pengantar Ilmu Hukum dan Tata Hukum Indonesia, Jakarta: Balai Pustaka, 2015, hlm. 41
}

tersebut didukung dan diperkuat oleh unsur-unsur yang apabila terdapat adanya praktik monopoli akan membedakan dan berorientasi kepada hasil dari kegiatan tersebut merugikan atau menguntungkan kepentingan umum. Tidaklah manusiawi apabila suatu lembaga yang memiliki kewenangan akan melakukan monopoli tidak mementingkan kepentingan umum untuk menjalankan tujuan negara. Menurut Subekti berdasarkan kutipan C.S.T Kansil mengemukakan bahwa hukum itu melayani tujuan negara dan pada dasarnya untuk membawa kemakmuran dan kebahagiaan bagi rakyat. $^{9}$

Substansi yang terdapat dalam Pasal 51 UU No. 5 Tahun 1999 menyatakan bahwa aturan pengecualian untuk melakukan monopoli yang dapat dilakukan oleh BUMN merupakan hal yang menimbulkan pro-kontra. Kewenangan istimewa yang dimiliki BUMN itulah yang harus dijalankan dan tidak boleh untuk melaksanakan praktek monopoli yang termasuk dalam kegiatan dilarang dalam Pasal 17 UU No. 5 Tahun 1999 yang mengatur lebih jelas tentang praktik monopoli. Lembaga KPPU yang berwenang dalam menangani permasalahan atau isu tentang persaingan usaha secara prinsipnya memang untuk mengawasi pelaksanaan undangundang. ${ }^{10}$ KPPU hingga saat ini sudah menangani berbagai permasalahan yang memang tidak ada habisnya mengenai persaingan usaha terhadap pelaku usaha yang melakukan salah satu kegiatan yang dilarang, yaitu praktik monopoli. ${ }^{11}$ Sebagaimana salah satu perkara yang dilaporkan kepada KPPU yaitu mengenai PT Pelabuhan Indonesia III selaku

\footnotetext{
10 Rai Manli, Hazar Kusmayan, Anita Afriana, Problemaka Penegakan Hukum Persaingan Usaha di Indonesia Dalam Rangka Menciptakan Kepasan Hukum, PJIH, Volume 3 Nomor 1, 2016

${ }^{11}$ Binoto Nadapdap, Hukum Acara Persaingan Usaha Pasca-Putusan Mahkamah Konstitusi. Jakarta: Kencana, 2020, hlm. 132
} 
BUMN di duga melanggar Pasal 17 Ayat (1) dan (2) huruf b UU No. 5 Tahun 1999.

Berdasarkan hal tersebut, penulis menyakini dan meneliti dalam proses penelitian ini apakah hal-hal yang dilakukan oleh PT Pelabuhan Indonesia III selaku BUMN benar adanya melanggar ketentuan dalam aturan UU No. 5 Tahun 1999 berdasarkan unsurunsur yang terdapat dalam Pasal 17 Ayat (1) dan (2) huruf b UU No. 5 Tahun 1999 tentang Larangan Praktik Monopoli dan Persaingan Usaha Tidak Sehat.

\section{METODE}

Metode yang digunakan oleh penulis ialah metode yuridis normatif. Metode tersebut dipakai dengan memeriksa bahan pustaka yang berupa data sekunder berupa penelitian hukum perpustakaan. ${ }^{12} \quad$ Lalu, penulis menggunakan sumber data berupa data sekunder yang terdiri dari tiga bahan bukum berupa bahan hukum primer, meliputi UUD Tahun 1945, UU No. 5 Tahun 1999, putusan KPPU Nomor 15/KPPU-L/2018. Bahan hukum sekunder, meliputi bahan yang mendukung dalam penelitian ini berupa jurnal-jurnal atau buku yang berkaitan tentang penelitian ini. Bahan hukum tersier, meliputi bahan-bahan yang memberikan penjelasan seperti pencarian data untuk menunjang penelitian menggunakan internet. ${ }^{13}$ MSelanjutnya, penulis dalam metode pengumpulan datanya melakukan dengan cara studi kepustakaan (library research). ${ }^{14}$ Sedangkan, teknik analisis data yang digunakan ialah metode kualitatif.

\section{HASIL DAN PEMBAHASAN}

\section{Pengecualian Terhadap BUMN}

Indonesia termasuk negara hukum, dimana penerapan dalam kehidupan berbangsanya memiliki tata hukumnya sendiri. Tata hukum yang berlaku saat ini diartikan sebagai hukum positif. ${ }^{15}$ Negara yang memiliki tata hukum tersebut harus bercermin untuk membuat suatu konstitusi yang berlandaskan kepentingan masyarakat atau warga negaranya tanpa ada kepentingan pribadi maupun golongan yang ingin mencari kesempatan dalam kesempitan.

Termasuk dalam salah satunya peraturan tentang aktivitas ekonomi yang sangat mempengaruhi hajat atau kemakmuran warga masyarakat jika ditunjang dengan peraturan yang dapat bermanfaat dan berguna bagi sesama. Sedangkan, selain adanya peraturan yang mengatur terdapat kebiasaan yang mendukung bagaimana sifat yang nyata dan berkembang di masyarakat itu menjadi suatu hal yang bermanfaat. Kemanfaatan itulah agar melindungi hakhak yang dimiliki setiap warga negara.

Salah satu hal yang mengatur tentang bagaimana peraturan mengenai aktivitas ekonomi di Indonesia, ialah mengenai aturan persaingan usaha. Di Indonesia aturan mengenai aspek persaingan usaha terdapat pada UU No. 5 Tahun 1999. Mengenai beberapa tujuan yang berlandaskan UUD Tahun 1945 yang berlandaskan ekonomi kerakyatan dan kekeluargaan, peraturan tersebut diharapkan menjadi tonggak peradaban yang menciptakan insan pelaku usaha dalam melakukan aktivitas ekonomi yang sehat dan tidak menimbulkan persaingan.

\footnotetext{
${ }^{14}$ Bambang Sunggono, Metode Penelitian Hukum, Jakarta: PT RajaGrafindo Persada, 2011, hlm. 112

15 Ishaq, Pengantar Hukum Indonesia, Jakarta: PT RajaGrafindo Persada, 2014, hlm. 5
}

\footnotetext{
12 Ediwarman, Metodologi Penelitian Hukum Yogjakarta: Genta Publishing, 2016, hlm. 21

${ }^{13}$ M. Nazil, Metode Penelitian, Jakarta: Ghalia Indonesia, 2010, hlm. 112
} 
Persaingan juga tidak selalu dapat dikatakan sebagai hal yang negatif, ${ }^{16}$ dimana persaingan juga dapat menciptakan hal positif. Adanya persaingan menciptakan pelaku usaha yang satu dan lainnya memikirkan suatu strategi pemasaran dalam usahanya dan menciptakan kestabilan suatu barang atau jasa tersebut menjadi stabil. Jika, tidak adanya persaingan maka dikhawatirkan adanya lonjakan harga yang akan mempengaruhi juga konsumen dalam menggunakan barang atau jasa tersebut. Hal lainnya dapat khawatirkan juga akan terjadinya praktik monopoli.

Praktik monopoli termasuk dalam kegiatan yang dilarang. Praktik monopoli dapat menimbulkan faktor-faktor yang akan merugikan konsumen maupun pelaku usaha lainnya yang bergerak dalam bidang barang atau jasa yang sama. Pemusatan kekuatan ekonomi yang dilakukan oleh salah satu pelaku usaha tersebutlah akan menciptakan persaingan usaha tidak sehat dan akan merugikan kepentingan umum. Latar belakang dari terbentuknya suatu konstitusi semestinya harus dapat mensejahterakan masyarakat dan memberikan keadilan, kemanfaatan serta kepastian hukum.

Salah satu bentuk lainnya mengenai praktik monopoli ialah adanya monopoli itu sendiri. Monopoli diartikan sebagai penguasaan atas produksi terhadap penjualan barang atau penggunaan jasa yang dilakukan oleh satu pelaku usaha. Monopoli sebagai bentuk dalam UU No. 5 Tahun 1999 ini mempunyai kewenangan dalam pengecualiannya untuk diberikan kepada BUMN.

Pengecualian diperbolehkannya BUMN untuk

\footnotetext{
${ }^{16}$ Yizzreel A. Alexander Sianipar, Skripsi, “Analisis Praktik Monopoli dan Diskriminasi Kasus Penjualan Jasa Asuransi Kecelakaan Penumpang Feri di

Teriminal Feri Kota Batam (Studi Putusan KPPU: No. 32/KPPU-L/2009”, Jakarta: UI, 2011, hlm. 17

${ }^{17}$ Muhammad Annas, Kegiatan Usaha PT Pelabuhan Indonesia Pasca Lahirnya Undang-Undang No.17
}

melakukan monopoli berlandaskan pada Pasal 51 UU No. 5 Tahun 1999. ${ }^{17}$ Aturan tersebut juga berlandaskan pada Pasal 33 UUD Tahun 1945 yang berbunyi "perekonomian disusun sebagai usaha bersama berdasar atas asas kekeluargaan", dimana atas dasar tersebut termasuk dalam "cabang produksi yang penting bagi negara dan menguasai hajat hidup orang banyak dikuasai oleh negara".

"Cabang produksi yang dikuasai oleh negara" yang diungkapkan dalam UUD Tahun 1945 tersebut sesuai dengan Pasal 51 UU No. 5 Tahun 1999 yang berbunyi "monopoli dan atau pemusatan kegiatan yang berkaitan dengan produksi dan atau pemasaran barang dan atau jasa yang menguasai hajat hidup orang banyak serta cabang-cabang produksi yang penting bagi negara diatur dengan undang-undang dan diselenggarakan oleh Badan Usaha Milik Negara dan atau badan atau lembaga yang dibentuk atau ditunjuk oleh Pemerintah". ${ }^{18}$ Dalam hal ini, definisi mengenai negara dalam Pasal 51 tersebut ialah abstrak. Subjek yang dapat dikatakan ialah negara itu tidak jelas dan kabur dari pemahaman. Namun, definisi yang ditunjukkan dalam Pasal 51 tersebut mengenai dikuasai oleh negara dapat dipahami sebagai negara memberikan kewenangan kepada Pemerintah untuk melaksanakan dan melakukan pengawasan terhadap pelaku usaha tersebut.

Dalam hal menerapkan peraturan tersebut, tidaklah serta merta pemerintah akan menunjuk suatu lembaga atau kewenangan BUMN dalam melakukan monopoli tersebut dengan sebebasbebasnya. ${ }^{19}$ Dengan adanya Pasal 51 UU

\footnotetext{
Tahun 2008 tentang Pelayaran dalam Perspektif Hukum Persaingan Usaha, Justisia Jurnal Hukum, Volume 1 No. 2, Oktober 2017, hlm. 344

${ }^{18}$ Lihat Pasal 51 UU No. 5 Tahun 1999

${ }^{19}$ Abdul Rahman, Op.Cit, hlm. 291
} 
No. 5 Tahun 1999 juga harus menilai dan menyatakan adanya batasan-batasan yang harus ditaati agar terciptanya pelaku usaha yang sehat dan menghindari adanya persaingan usaha secara tidak sehat. Adanya batasan-batasan tersebut salah satunya harus mengedepankan prinsip-prinsip persaingan secara sehat.

Bunyi dari Pasal 51 UU No. 5 Tahun 1999 sebetulnya sudah menyinggung mengenai adanya pemusatan kegiatan. Pemusatan kegiatan itu sendiri telah jelas diatur dalam aturan sebelumnya dalam undang-undang yang sama, jelasnya diatur dalam Pasal 1 Ayat (2) dan (3), dimana adanya pemusatan kegiatan berpotensi menimbulkan praktik monopoli. Dalam penjabarannya tersebut maka Pasal 51 UU No. 5 Tahun 1999 bukan bersifat pelarangan, melainkan pengecualian. Monopoli yang diberikan kepada BUMN ialah monopoli yang bersifat alamiah. Kewenangan BUMN dalam pengecualian tersebut diupayakan untuk menghindari adanya eksploitasi bentuk monopoli yang tidak terkontrol. Kewenangan yang dimiliki BUMN tersebut juga harus mesti di awasi dengan baik dengan penerapannya di lapangan. ${ }^{20}$

Penunjukkan BUMN yang dapat melakukan monopoli juga menjadi permasalahan bahwa BUMN mana yang dapat ditunjuk oleh Pemerintah. Perusahana yang dapat dikatakan sebagai BUMN ini dapat menjadi celah bagi pelaku usaha swasta yang memang ingin bertujuan untuk kepentingan pribadi dan menjauhi tujuan mewujudkan kepentingan umum tersebut dalam hal privatisasi yang diatur dalam UndangUndang Nomor 19 Tahun 2003. Meninjau bahwa BUMN dapat dimasuki oleh pelaku usaha swasta, diperlukan batasan yang diatur dalam Pedoman Pasal 51 UU No. 5 Tahun 1999.
Tujuan dibentuknya Pedoman tersebut selain memberikan secara gambaran umum mengenai batasan dalam pengecualian BUMN untuk melakukan monopoli, selain itu pedoman dapat memberikan kriteria BUMN mana yang dapat menyelenggarakan monopoli agar tidak terjadinya praktik monopoli atau persaingan usaha tidak sehat. BUMN yang sesuai dengan kriteria tersebut harus melalui proses dan penetapan analisis yang panjang dan komprehensif demi mewujudkan adanya BUMN melaksanakan tugas dan fungsinya secara baik dan benar. Salah satunya keharusan lembaga BUMN yang diatur dalam undang-undang. Disinyalir adanya kekhawatiran dalam praktik monopoli inilah salah satunya kebijakan penerapan biaya yang menjadi keistimewaan BUMN untuk monopoli seharusnya dilakukan pengawasan yang sangat intens oleh Pemerintah.

Pengawasan yang ditujukan oleh BUMN tersebut harus dilaksanakan oleh Pemerintah dengan melaksanakan beberapa hal. Persoalan mengenai aspek hukum persaingan usaha yang ditinjau dari Pasal 51 UU No. 5 Tahun 1999 ini sebenarnya sudah tidak mencerminkan aspek keadilan yang bertujuan sebagai fungsi hukum. Mengenai perbedaan yang diatur dalam melakukan monopoli ini seharusnya dapat berubah aturannya mengikuti era yang berlaku dan perlu berbagai kajian kembali terhadap aturan undang-undang ini untuk di revisi dan perbaiki melihat dari sudah banyak kasus BUMN yang terlibat praktik monopoli, contohnya dalam penelitian ini mengenai PT Pelabuhan Indonesia III selaku BUMN diputuskan oleh KPPU melanggar Pasal 17 Ayat (1) dan (2) huruf b UU No. 5 Tahun 1999.

\footnotetext{
${ }^{20}$ Susanti Adi, Hukum Persaingan Usaha di Indonesia, Jakarta: Kencana, 2012, hlm. 255
} 


\section{PT Pelabuhan Indonesia III dalam Hal Praktik Monopoli}

Berdasarkan pemahaman diatas mengenai pengecualian terhadap BUMN, maka penulis mengangkat penelitian ini dengan menghubungkan kaitannya terhadap perusahaan BUMN yang bernama PT Pelabuhan Indonesia III. Apakah dalam perkara yang dilakukan PT Pelabuhan Indonesia III ini dapat dikecualikan atau tidak dalam Pasal 51 UU No. 5 Tahun 1999 tersebut.

PT Pelabuhan Indonesia III terbentuk berdasarkan PP No. 58 Tahun 1991. Atas dasar aturan tersebut PT Pelabuhan Indonesia III dinyatakan sebagai perusahaan BUMN oleh Pemerintah. Kepercayaan itu juga tak hanya berasal dari peraturan pemerintah, melalui UU No.17 Tahun 2008 tentang Pelayaran, perusahaan tersebut diberi mandat untuk melaksanakan kegiatan kepelabuhanan oleh Pemerintah.

Atas dasar tersebut ditunjuknya suatu perusahaan BUMN yang dimana dalam hal ini PT Pelabuhan Indonesia III terpenuhi sesuai dengan syarat penunjukkan BUMN pada kewenangan dalam menjalankan Pasal 51 UU No. 5 Tahun 1999 tersebut. Dengan hal tersebut, maka PT Pelabuhan Indonesia III dengan penerapannya harus menjalankan perusahaannya demi kepentingan umum dan tidak menimbulkan kerugian bagi siapapun, termasuk negara yang harus dapat benefit yang lebih dalam penguasaan mengenai monopoli tersebut.

PT Pelabuhan Indonesia III berpusat di Surabaya dan menguasai beberapa pelabuhan yang ada di Indonesia, salah satunya di Pelabuhan L.

\footnotetext{
${ }^{21}$ PT Pelindo III, "Sejarah PT Pelindo III" http://www.pelindo.co.id, diakses: 1 April 2021.

22 Amir Baihaqi, "KPPU Vonis Pelindo III Bersalah Kasus Wajib Stack di Pelabuhan L. Say Maumere" http://news.detik.com/berita-jawa-timur/d-4678344/, diakses: 28 Februari 2021
}

Say Maumere, NTT. $^{21}$ Dalam kegiatannya tersebut pula, PT Pelabuhan Indonesia III dilaporkan oleh KPPU dalam perkara nomor 15/KPPU-L/2018 dengan dugaan adanya praktik monopoli. $^{22}$ Kewenangan suatu perusahaan BUMN dalam melakukan monopoli memang kemungkinan akan mengakibatkan dengan rentan terjadinya praktik monopoli akibat disalahkannya kewenangan istimewanya demi kepentingan pribadi maupun golongan.

Adanya dugaan tersebut perlu di dasari dengan pembuktian, apakah benar dan tepat PT Pelabuhan Indonesia III itu melakukan praktik monopoli yang secara langsung menciderai pula UU No. 5 Tahun 1999 tersebut. Padahal dalam penerapannya PT Pelabuhan Indonesia III mempunyai kewenangan terhadap Pasal 51 untuk melakukan monopoli.

Mengenai kewenangan BUMN untuk monopoli dalam penerapan Pasal 51 tersebut, dalam pedomannya memang dijelaskan dengan rinci bagaimana monopoli dan praktik monopoli itu suatu hal yang dibedakan. Monopoli itu sendiri memang keharusan yang dilaksanakan oleh negara memberikan kewenangannya terhadap Pemerintah untuk menunjuk suatu lembaga atau perusahaan BUMN yang jelas fungsinya untuk mensejahterakan negara dalam menerapkan kebijakan. ${ }^{23}$

Dalam ketentuan mengenai Pasal 51 dan pedoman yang dimiliki KPPU terhadap pasal tersebut menyakini bahwa PT Pelabuhan Indonesia III ialah BUMN yang dapat menjalankan monopoli dan memenuhi unsur diantaranya dibentuk oleh undang-undang.

Pedoman itu juga memberikan contoh pemahaman bahwa dalam

\footnotetext{
${ }^{23}$ Ningrum Natasya, Hukum Persaingan di Indonesia UU No. 5/1999 tentang Larangan Praktik Monopoli dan Persaingan Usaha Tidak Sehat, Medan: Pustaka Press, 2011, hlm. 85
} 
penerapan pasal tersebut kemungkinan akan terjadi penyimpangan yang dilakukan, baik itu BUMN atau lembaga yang ditunjuk oleh Pemerintah. Dimana salah satunya, mengenai kasus monopoli yang mengarah pada terjadinya praktik monopoli. Dalam menetapkan adanya praktik monopoli, majelis KPPU harus dapat membuktikan semua bahwa suatu subjek yang di duga melakukan praktik monopoli dengan unsur-unsur yang terdapat di dalamnya.

Dalam perkara ini, PT Pelabuhan Indonesia III selaku BUMN yang bergerak dalam bidang kepelabuhanan mengoperasikan salah satu pelabuhan yang bernama Pelabuhan L. Say Maumere, NTT. Pelabuhan tersebut termasuk pelabuhan serba guna (multipurpose). PT Pelabuhan Indonesia III yang dipercayai oleh Pemerintah untuk mengelola dan dijadikannya perusahaan tersebut menjadi BUP dalam pelabuhan itu merubah pengelolaan sistem jasa bongkar muat yang sebelumnya menggunakan sistem Truck Lossing menjadi stack $100 \%$ artinya dalam penggunaan jasa bongkar muat petikemas yang sebelumnya langsung diantarkan menggunakan transportasi ini ditumpuk terlebih dahulu semuanya di pelabuhan dan mengakibatkan kenaikan biaya kepada pihak yang terlibat. Karenanya itu juga mengakibatkan adanya dampak yang ditimbulkan.

Pembuktian diperlukan dengan memperkuat dalam memenuhi unsurunsur yang kemungkinan terjadi praktik monopoli. Majelis KPPU mengeluarkan putusan nomor 15/KPPU-L/2018 yang dimana majelis KPPU menghukum PT Pelabuhan Indonesia melanggar Pasal 17 Ayat (1) dan (2) huruf b UU No. 5 Tahun 1999. Unsur-unsur tersebut diantaranya unsur pelaku usaha, penguasaan atas

\footnotetext{
${ }^{24}$ Fitrah Akbar, Hukum Persaingan Usaha Penerapan Rule Of Reason Dalam Penanganan Praktik Kartel, Yogyakarta:Suluh Media, 2017, hlm. 34
}

produksi, barang atau jasa, unsur mengakibatkan praktik monopoli dan unsur persaingan usaha tidak sehat, unsur mengakibatkan pelaku usaha lain tidak dapat masuk ke dalam pasar. Semua unsur-unsur tersebut harus dibuktikan dengan seksama dan sejelas-jelasnya dengan pendekatan Rule of reason. ${ }^{24}$

Pertama, unsur pelaku usaha. Unsur ini pada dasar tercantum pada Pasal 1 Angka 5 UU No. 5 Tahun 1999. ${ }^{25}$ Pelaku usaha yang dimaksud dalam hal ini sudah jelas ialah PT Pelabuhan Indonesia III itu sendiri dengan dasar berdirinya PP No. 58 Tahun 1991.

Kedua, unsur penguasaan atas produksi. Dalam hal ini diatur dalam Peraturan KPPU Nomor 11 Tahun 2011. Penguasaan pasar bersangkutan yang terdapat dalam objek ini ialah PT Pelabuhan Indonesia yang menjadi BUP berdasar pada KP Nomor 88 Tahun 2011 terhadap pelabuhan L. Say Maumere. Maka dengan hal tersebut, PT Pelabuhan Indonesia III yang mempunyai kewenangan dalam mengelola pelabuhan tersebut melakukan penataan pelayanan terminal terhadap perusahaan yang bergerak dibidang pelabuhan lainnya yang didasari akibat dari PT Pelabuhan Indonesia menjadi BUP. Dengan hal itu, perusahaan lain tidak bisa memberikan pelayanan dengan cara mandiri karena pelabuhan L. Say Maumere tidak memiliki terminal lain.

Ketiga, unsur barang atau jasa. Definisi mengenai barang atau jasa itu sendiri diatur dalam Pasal 1 Angka 2 UU No. 5 Tahun 1999. ${ }^{26}$ Dalam hal ini, barang yang dimaksud ialah jasa bongkar muat petikemas dan jasa yang dimaksud ialah jasa kepelabuhanan.

Keempat, unsur mengakibatkan praktik monopoli. Praktik monopoli dalam teorinya mempunyai definisi

\footnotetext{
${ }^{25}$ Pasal 1 Angka 5 UU No. 5 Tahun 1999

${ }^{26}$ Pasal 1 Angka 2 UU No. 5 Tahun 1999
} 
penyalahgunaan posisi monopoli. Monopoli yang disalahgunakan dalam kegiatannya yang mengakibatkan terjadinya praktik monopoli, kegiatan tersebut memiliki beberapa unsur juga, seperti eksploitasi, pencegahan, pembatasan, dan penurunan persaingan. Hal-hal tersebut yang menjadi dasar bagaimana suatu perusahaan dapat melakukan praktik monopoli dan dinyatakan menciderai aturan hukum persaingan usaha yang berlaku. PT Pelabuhan Indonesia III dalam hal tersebut dilaporkan dengan melakukan kebijakan pola pelayanan terminal petikemas. Kebijakan tersebut bertentangan dengan status pelabuhan L. Say Maumere itu sendiri, dimana status pelabuhan tersebut ialah sebagai terminal multiguna yang artinya tidak harus hanya digunakan sebagai terminal petikemas. Dengan hal tersebut pula, kegiatan yang dilakukan oleh PT Pelabuhan Indonesia III mengakibatkan adanya kerja sama dengan jasa kepelabuhanan terkait yang berakibat hilangnya persaingan di pasar. Dengan hilangnya persaingan itulah, maka terjadi kenaikkan biaya yang ditanggungkan kepada pelaku usaha lainnya.

Kelima, unsur mengakibatkan pelaku usaha lain tidak dapat masuk ke dalam pasar. Dimana dalam hal ini, PT Pelabuhan Indonesia III menggunakan penguasaan pasarnya tersebut dan adanya hubungan dengan jasa kepelabuhanan terkait dengan akibat yang dirasakan oleh pelaku usaha lainnya.

Dengan kelima unsur tersebut, maka PT Pelabuhan Indonesia III dinyatakan bersalah melanggar Pasal 17 Ayat (1) dan (2) oleh majelis KPPU. Meninjau dari beberapa unsur tersebut, diyakini bahwa unsur tersebut menjadi final dengan adanya kegiatan yang dilakukan yang jelas merugikan kepentingan umum tidak dapat dikecualikan pada Pasal 51 UU No. 5
Tahun 1999. Unsur tersebut menjadi dasar bahwa perusahaan yang memiliki kewenangan dalam melakukan monopoli juga harus dilakukan pengawasan agar tidak terjadi praktik monopoli, seperti PT Pelabuhan Indonesia III tersebut.

Ditinjau dari aturan mengenai konsensi terhadap PT Pelabuhan Indonesia III untuk mengelola kegiatan kepelabuhanan menjadi dasar perusahaan tersebut merubah pengelolaan sistem. Tetapi, dengan cara tersebut mengakibatkan adanya kenaikan biaya yang merugikan pelaku usaha lain untuk menggunakan jasa terkait kepelabuhanan itu. Padahal perubahan pola pelayanan itu mendapat penolakan dari berbagai unsur masyarakat dan ahli, dimana sejatinya pelabuhan L. Say Maumere bukan menjadi pelabuhan yang bertitik fokus pada jasa bongkar muat petikemas, melainkan pelabuhan multiguna atau umum.

Dengan adanya perkara mengenai praktik monopoli yang dilakukan oleh perusahaan BUMN ini seharusnya menjadi pembelajaran bahwa harus adanya perubahan pola aturan yang diwajibkan kepada pelaku usaha lain itu mempunyai hak yang sama. Pada dasarnya pengelolaan apapun mengenai aktivitas ekonomi akan berlari juga kepada Pemerintah dan negara itu sendiri dalam mendapatkan hasil. Karenanya pengelolaan yang dilakukan oleh perusahaan itu juga harus dianalisa dan di awasi dengan baik. Sebagai lembaga regulator, KPPU menjadi lembaga satusatunya yang menaungi permasalahan persaingan usaha. Dengan tugas dan pokok yang dimiliki diharapkan dapat menuntasi semua kegiatan persaingan usaha menjadi sehat. Dunia bisnis ialah dunia yang kompetitif, lalu bagaimana cara bersaing secara sehat, di sinilah KPPU berperan.

\section{PENUTUP}


Pengecualian terhadap Pasal 51 UU No. 5 Tahun 1999 mengenai kewenangan BUMN untuk melakukan monopoli harus diselaraskan dengan implikasi yang terjadi dalam pelaksanaannya di lapangan. Kenyataan yang tidak sesuai dengan penerapan yang berlaku. Indikasi yang sejalan dengan adanya peraturan mengenai hukum persaingan usaha harus dijalankan dengan seadil-adilnya. BUMN sebagai perusahaan atau lembaga yang memiliki kewenangan berbeda dengan pelaku usaha lainnya yang diberikan keistimewaan harus dilihat kembali dan ditinjau berdasarkan prinsip persaingan usaha secara sehat. Diperlukannya pengawasan ekstra dari berbagai unsur yang terlibat mengenai persaingan usaha harus dijalankan dengan sebaik-baiknya, pengawasan tersebut harus dilaksanakan oleh Pemerintah dengan melaksanakan berbagai hal, salah satunya dalam pertanggungjawaban dari setiap kegiatannya. Masih banyak terjadi praktik monopoli yang dilakukan oleh perusahaan BUMN tertentu yang sebagaimana berlaku dan ditunjuk oleh Pemerintah. Dalam putusan KPPU Nomor 15/KPPU-L/2018 ini PT Pelabuhan Indonesia III yang bergerak sebagai BUMN melakukan dan terbukti melanggar Pasal 17 Ayat (1) dan (2) UU No. 5 Tahun 1999, dimana menciderai kewenangan Pasal 51 UU No. 5 Tahun 1999, serta Pasal 33 UUD Tahun 1945.

Dari salah satu perkara tersebut, penulis memberikan rekomendasi agar memang diperlukannya perubahan dalam UU No. 5 Tahun 1999 ini dapat memberikan keadilan yang semestinya untuk semua pelaku usaha, terutama dalam pengecualian terhadap BUMN ini agar tidak terjadinya praktik monopoli.

\section{DAFTAR PUSTAKA}

\section{Buku}

Adi, Susanti. 2012. Hukum Persaingan

Usaha di Indonesia. Jakarta:

Kencana.

Ediwarman. 2016. Metodologi Penelitian

Hukum. Yogjakarta: Genta

Publishing.

Ishaq. 2014. Pengantar Hukum

Indonesia, Jakarta: PT

RajaGrafindo Persada.

Kansil, C.S.T. 2015. Pengantar Ilmu

Hukum dan Tata Hukum

Indonesia. Jakarta: Balai

Pustaka.

Nadir. 2015. Membidik Persaingan Tidak

Sehat Dengan Hukum Anti

Monopoli dan Persaingan Tidak

Sehat. Malang: UB Press.

Nazil, M. 2010. Metode Penelitian.

Jakarta: Ghalia Indonesia.

Natasya, Ningrum. 2011. Hukum

Persaingan di Indonesia UU No.

5/1999 tentang Larangan

Praktik Monopoli dan

Persaingan Usaha Tidak Sehat.

Medan: Pustaka Press

Radbruch, Gustav. 1961. Einfuhrung in die Rechtswissenchaft, Stugart:

K.F.Koechler.

Rahman, Abdul. 2018. Hukum

Persaingan Usaha. Sleman:

Deepublish.

Sunggono, Bambang. 2011. Metode Penelitian Hukum. Jakarta: PT

RajaGrafindo Persada.

Erwin, Muhammad. 2017. Pendidikan

Kewarganegaraan Republik

Indonesia, Bandung: PT Refika

Aditama

Akbar, Fitrah. 2017. Hukum Persaingan

Usaha Penerapan Rule of

Reason Dalam Penanganan

Praktik Kartel, Yogyakarta:

Suluh Media. 
Nadapdap, Binoto. 2020. Hukum Acara

Persaingan Usaha Pasca-

Putusan Mahkamah Konstitusi.

Jakarta: Kencana.

Jurnal

Manli, Hazar, Anita. 2016. Problemaka

Penegakan Hukum Persaingan

Usaha di Indonesia Dalam

Rangka Menciptakan Kepasan

Hukum, PJIH, Volume 3 No. 1

Annas, Muhammad. 2017. Kegiatan

Usaha PT Pelabuhan Indonesia

Pasca Lahirnya Undang-Undang

No.17 Tahun 2008 tentang

Pelayaran dalam Perspektif

Hukum Persaingan Usaha,

Justisia Jurnal Hukum, Volume

1 No. 2

Skripsi, Tesis, Disertasi, Laporan

Sianipar, Alexander. 2011. Analisis

Praktik Monopoli dan

Diskriminasi Kasus Penjualan

Jasa Asuransi Kecelakaan

Penumpang Feri di Teriminal

Feri Kota Batam (Studi Putusan

KPPU: No. 32/KPPU-L/2009.

Skripsi. Jakarta: UI

Internet

Amir Baihaqi, "KPPU Vonis Pelindo III

Bersalah Kasus Wajib Stack di

Pelabuhan L. Say Maumere" http://news.detik.com/beritajawa-timur/d-4678344/, diakses: 28 Februari 2021

PT Pelindo III, "Sejarah PT Pelindo III" http://www.pelindo.co.id, diakses: 1 April 2021.

\section{Perundang-undangan}

Republik Indonesia. UUD Tahun 1945

Republik Indonesia. UU Nomor 5 Tahun 1999 tentang Larangan Praktek Monopoli dan Persaingan Usaha Tidak Sehat. 